\title{
Changes in Proximate Composition during Processing of a Few Rice Products of Assam having Ethno-Economic Importance
}

\author{
Suchandra Bhattacharjee and Priyanka Das* \\ Department of Biochemistry and Agricultural Chemistry, \\ Assam Agricultural University, Jorhat-785013, India \\ *Corresponding author
}

\begin{tabular}{l} 
Ke y w o r d s \\
Food crops \\
$\begin{array}{l}\text { World's population, } \\
\text { Rice varieties }\end{array}$ \\
\hline Article Info \\
\hline $\begin{array}{l}\text { Accepted: } \\
\text { 07 March } 2020 \\
\text { Available Online: } \\
\text { 10 April } 2020\end{array}$ \\
\hline
\end{tabular}

\section{A B S T R A C T}

Rice is one of the world's most important food crops and more than half of the world's population depends on rice as a primary source of food. Due to processing, alteration of nutritional quality takes place either by changes in nutrients or by an improvement in digestibility of nutrients. Hurum, komal chaul, bhoja bora, puffed rice, popped rice, flaked rice, korai, sandahguri are the rice products obtained from specialty rice varieties of Assam, particularly bora (low amylose containing) and chakua (intermediate amylose containing). A unique characteristic of these rice products is that the products can be used instantly. In the present study, decrease for moisture, total carbohydrate and crude fat content and increase for crude protein, crude fibre and ash content were observed in the products than their respective raw forms. The moisture content of specialty rice and their products were found to be $6.55 \%-14.43 \%$. On dry weight basis, the total carbohydrate, crude protein, crude fat, crude fibre, total ash and energy content of specialty rice and their products ranged between $88.53 \%$ $92.17 \%, 5.83-9.20 \%, 0.10-0.41 \%, 0.62-1.13 \%, 0.66-1.34 \%$ and $392.18-$ $395.95 \mathrm{kcal} / 100 \mathrm{~g}$, respectively.

\section{Introduction}

Rice is one of the world's most important food crops and more than half of the world's population depends on rice as a primary source of food (Atungulu and Pan, 2014). It provides $715 \mathrm{kcal}$ energy/capita/day in developing countries. It also provides $27 \%$ of dietary energy supply, $20 \%$ of dietary protein and $3 \%$ of dietary fat (Kennedy and Burlingame, 2003). Rice protein, though lacks in lysine is considered to be of high quality 
and well balanced as all the eight essential amino acids are present in proper proportion (Mahadevamma and Tharanathan, 2007).

Rice is an excellent source of energy, in the form of starch, and it provides proteins of higher nutritional quality (Pinkrova et al., 2003). Different processing methods are used in food industry worldwide to produce various rice products with desirable quality based on cultural and cooking demand and nutritional considerations. These processes result in variable degree of macro and micro nutrient content, stability, retention, etc depending on nutritional quality and rice variety. Brown rice is richer in protein, minerals, vitamins and lysine content compared with milled rice. Rice milling is the major processing method that significantly changes rice nutritional quality (Atungulu and Pan, 2014).

In Assam, a variety of traditional ready to eat products from rice are processed, in which parboiling is involved. Due to processing, alteration of nutritional quality takes place either by changes in nutrients or by an improvement in digestibility of nutrients. Hurum, komal chaul, bhoja bora, puffed rice, popped rice, flaked rice, korai, sandahguri are the rice products obtained from specialty rice varieties of Assam, particularly bora (low amylose containing rice) and chakua (intermediate amylose containing rice). A unique characteristic of these rice products is that the products can be used instantly.

Banik, et al., (2018) reported about the composition of ready to use ethnic rice products of Assam, India as potential source of resistant Starch. The present authors (Bhattacharjee et al., 2019) reported the biochemical changes of carbohydrate profiling taking place during processing of the traditional rice products of Assam having ethno economic importance. Except this, no reports can be traced on biochemical changes taking place during processing of specialty rice products of Assam. Considering limited information on the proximate composition of the traditional rice products of Assam having ethno economic importance together with the changes involved during processing, the present work was carried out.

\section{Materials and Methods}

\section{The rice and the products}

The specialty rice products Bhoja bora, Korai, Komal chaul and Sandahguri along with the intermittent form 1 (for bhoja bora) and the respective raw/ brown form of rice were collected from Jamuguri village near the campus of Assam Agricultural University, Jorhat, Assam.

The specialty rice products Hurum and flaked rice along with the intermittent form 2 (for hurum) and the respective raw/ brown form of rice were collected from Pukhuria village near Mariani, Jorhat. All the specialty rice products were obtained through traditional method.

\section{Bhoja bora}

Michi bora paddy (about $400 \mathrm{gm}$ ) was soaked in normal water for 24 hours at room temperature and after that, water was drained out. At this stage the sample was collected to be analyzed as intermittent product 1(after dehusking). The paddy was then fried in an iron vessel over wood fire with constant stirring for about 20 mins (The grain temperature recorded to be approximately $105^{\circ} \mathrm{C}$ ). Cooling was done by spreading these grains over mud floor for few mins before milling in a dheki (foot operated wooden traditional milling device). Lastly, sieving was done to get bhoja bora chaul 


\section{Korai}

Korai was prepared by frying the dehusked whole michi bora rice on hot pan with constant stirring for about 3 mins (approximately at $100^{\circ} \mathrm{C}$ ). Then grinding was done using domestic mixer grinder. Then sieving was done using $50 \mu$ sieve to get the final product korai.

\section{Hurum}

Bakul bora paddy (about $200 \mathrm{gm}$ ) was soaked in normal water for 24 hours at room temperature and then treated with boiling water for about 10 mins. After draing the water, the paddy was fried in an iron vessel over wood fire with constant stirring for about 15 mins (approximately at $103^{0} \mathrm{C}$ grain temperature). It was followed by cooling, which was done by spreading these grains over mud floor for few mins. After completion of cooling, the sample was collected for analysis as intermittent product 2 (after dehusking). The previous step was followed by milling using a dheki. After sieving, it was again fried in sand for about 3 min (approximately at temperature $45^{\circ} \mathrm{C}$ ). Lastly, sieving was done to get the product hurum.

\section{Flaked rice}

Bakul bora paddy (about 200 gm) was soaked in normal water for 24 hours at room temperature and then room shading was done for few mins. Then the paddy was roasted in an iron vessel over wood fire with constant stirring for about 3 mins (approximately at $\left.90^{\circ} \mathrm{C}\right)$.

Cooling was done by spreading these grains over mud floor for few min before milling in a dheki. Lastly, sieving was done to remove the husk and the flaked rice was collected.

\section{Komal chaul}

Ronga chakua paddy (about 400 gm) was soaked in normal water for 24 hours at room temperature and after draining the water, it was treated with warm (approximately at $78^{\circ} \mathrm{C}$ ) water for about 25 min over wood fire till the husk started splitting. The water is again drained and the grains were dried under the Sun on the same day. Dried grains were milled in a dheki. Lastly, sieving was done to remove the husk and the product komal chaul was collected.

\section{Sandahguri}

Sandahguri was prepared by frying the specialty rice product komal chaul on hot pan with constant stirring for about 6 mins (approximately at $101^{\circ} \mathrm{C}$ ). Then grinding was done in domestic mixer grinder. Then sieving was done using $50 \mu$ sieves (optional) to get the final product sandahguri.

\section{Biochemical methods}

The moisture content, ash content, crude fibre content, crude fat content and total nitrogen content (total nitrogen content was multiplied by the factor 5.95 to get crude protein content) were determined by following the method of AOAC (2000).

The total carbohydrate content on dry weight basis was calculated by subtracting the sum of the values (\%) of crude protein, ash, crude fat and crude fibre content (all on dry weight basis) from 100 (Gopalan et al., 2000). The energy value of different products was calculated according to Gopalan et al., (2000).

The data obtained from various biochemical analyses were subjected to statistical analysis using completely randomized design. 


\section{Results and Discussion}

\section{The moisture content}

The moisture content of specialty rice and their products is presented in Table 1 and Figure 1. In the present study, the moisture content of brown form of specialty rice was found to be $11.51 \%$ to $14.05 \%$, the lowest was observed in Michi bora and the highest was in Ronga chakua. Similar observations was reported by Das et al., (2018) for some brown form of chakua rice varieties of Assam $(10.1-11.8 \%)$. However, in the present investigation the moisture content of brown form of specialty rice was found to be higher than the values $(8.29 \%-10.10 \%$ for some hill rice cultivars of Assam and 8.33\% - 10.74\% for some glutinous rice cultivars of Assam) reported by Pathak (2008) and Pathak (2015), respectively. The significant variation in the moisture content of different specialty rice varieties (raw forms) might be due to the varietal differences.

In the present study, the moisture content of different products and their intermittent forms varied from $6.55 \%-14.05 \%$, the lowest was observed in bhoja bora and the highest was in the intermittent form 2. Similar observation (Komal chaul, Bhoja chaul, Flaked rice, Hurum, Sandahguri and Korai to be $11.52 \%$, $11.61 \%, 10.71 \%, 6.79 \%, 5.83 \%$ and $7.11 \%$, respectively) was reported by Banik et al., (2018) for some traditional rice products of Assam. Kumar et al., (2016) reported that the moisture content of thick flaked rice and extra thin flaked rice were $10.20 \%$ and $9.81 \%$, respectively which was lower than the moisture content of flaked rice $(13.43 \%)$ observed in the present investigation. . In the present study, the moisture content of bhoja bora $(6.55 \%)$ and sandah guri $(8.51 \%)$ were found to be lower than the values (for bhoja bora $14.04 \%$ and for sandahguri $12.66 \%$ ) reported by Barooah et al., (2018) for some traditional breakfast cereals of Assam. Kumar and Prasad, (2018) reported that the moisture content of roasted rice and flaked rice were $17.40 \pm 0.49 \%$ and $10.22 \pm 0.39 \%$, respectively. However, in the present study, higher moisture content of flaked rice $(13.43 \%)$ was observed.

The specialty paddy (Bakul bara) were soaked overnight, due to this the moisture content in the intermittent form 2 (dehusked) was found to be higher than its raw form. Kumar and Prasad, (2018) also observed higher moisture content in roasted rice as compared to brown and suggested that the increase was due to initial soaking step. However, the observed decrease in moisture content might be due to the step of roasting or frying followed during processing of the specialty rice products. Kumar and Prasad, (2018) suggested that roasting of paddy could reduce the moisture content which further reduced on milling. In the present study also moisture content of the specialty rice products was lower than their intermittent forms.

\section{The total carbohydrate content}

The total carbohydrate content of specialty rice and their products is presented in Table 1 and Figure 2. The total carbohydrate content of brown form of specialty rice was found to be $91.12 \%$ to $92.17 \%$. The lowest was observed in Ronga chakua and the highest in Bakul bora. However, in the present investigation, the total carbohydrate content of raw form of specialty rice was found to be higher than the values $(69.30 \%-85.90 \%)$ reported for brown form of chakua rice varieties of Assam by Das et al., (2018). The values observed in the present study were also found to be slightly higher than the values (80.62\%- $90.80 \%)$ reported for few indigenous red grained cultivars of Assam by Mudoi and Das, (2018). The significant variation in the total carbohydrate content of 
raw form of specialty rice might be mainly due to the genetic differences among the rice varieties used for processing.

The total carbohydrate content of different products and their intermittent forms varied from $88.53 \%$ to $91.63 \%$, the lowest was observed in sandah guri and the highest in the intermittent form 2. Similar observations (Komal chaul, Bhoja chaul, Flaked rice, Hurum, Sandahguri, and Korai to be $90.28 \%$, $88.67 \%, 89.48 \%, 89.33 \%, 90.07 \%$, and $89.30 \%$, respectively) were reported by Banik et al., (2018) for some traditional rice products of Assam. The total carbohydrate content for popped rice was reported to be $83.4 \%-85.9 \%$ by Puangjinda et al., (2016). Kumar and Prasad, (2018) reported that the total carbohydrate content of roasted rice and flaked rice were $70.69 \pm 0.69 \%$ and $77.75 \% \pm 0.60 \%$, respectively in comparison to $77.57 \pm 0.22 \%$ in raw form. In the present study, higher total carbohydrate content of flaked rice $(90.47 \%)$ was observed.

In the present study too, the total carbohydrates content of komal chaul and Ronga chakua were observed to be $88.97 \%$ and $91.12 \%$, respectively suggesting a decrease during processing. The similar trend (decrease in the content than their respective raw form) was observed for some of the products and intermediate forms, which might be due to loss during soaking, as it causes the leaching of rice constituents in the soaking water.

Starch and amylose content of rice decreases due to leaching of starch granules thereby reducing rice quality (Kale et al., 2015). In the present study too, the decrease in total carbohydrate was associated with decrease in starch and amylose content, as we have reported earlier (Bhattacharjee et al., 2019) and we observed that, in comparison to the decrease in starch content, the decrease in total carbohydrate content was not much, which might be due to conversion of starch to sugars during the step involved in frying/ heating. Earlier, it was reported that severe heating for prolonged time might lead to rapture of glycosidic linkages (Svihus et al., 2005).

\section{The crude fibre content}

The crude fibre content of specialty rice and their products is presented in Table 1 and Figure 3. The crude fibre content of brown form of specialty rice were found to be $0.62 \%$ to $0.93 \%$, the lowest was observed in Bakul bora and the highest in Ronga chakua. The result did not vary from the range reported by Das et al., (2018) for some brown form of chakua rice varieties of Assam (0.25\% $1.65 \%)$. The significant variation in the crude fibre content of different brown forms of specialty rice might be due to the variations in varieties.

The crude fibre content of different products and their intermittent forms varied from $0.71 \%-1.13 \%$, the lowest was observed in intermittent form 2 and the highest in bhoja bora. Similar observations were reported by Banik et al., (2018) for some traditional rice products of Assam (Komal chaul, Bhoja chaul, Flaked rice, Hurum, Sandahguri, and Korai to be $0.90 \%, 1.04 \%, 0.69 \%, 0.63 \%$, $1.04 \%$, and $0.62 \%$, respectively and Das et al., (2018) for some cereals and pulse based recipes of Assam $(0.2 \pm 0.00 \mathrm{~g} / 100-2.2 \pm 0.41$ $\mathrm{g} / 100)$, respectively.

In the present investigation, the crude fibre content of rice and their intermittent forms were found to be lower than the values (1.47\%) reported by Kumar et al., (2016) for thick flaked rice. Kumar and Prasad, (2018) reported that the crude fibre content of roasted rice and flaked rice were $1.35 \pm 0.28$ $\mathrm{g} / 100$ gand $1.54 \pm 0.05 \mathrm{~g} / 100 \mathrm{~g}$, respectively. In the present study, the lower crude fibre 
content of flaked rice $(0.77 \%)$ was observed.

Kashyap and Mahanta, (2016) reported that in raw Teli chowkua and Kola bora paddy crude fibre content were $0.3 \%$ and $0.2 \%$, respectively whereas, in kumal chawl, crude fibre content increased to $0.4 \%$ and $0.3 \%$, respectively.

They concluded that after parboiling the crude fibre content increased. In the present study also the crude fibre content of raw form of ronga chowkua was $0.93 \%$ which increased in komal chawl to $1.01 \%$. The observed increase in crude fibre content might be due to increase in percentage, not actual increase.

\section{The crude fat content}

The crude fat content of specialty rice and their products is presented in Table 1 and Figure 4. The crude fat content of brown form of specialty rice was found to be $0.35 \%$ to $0.41 \%$, the lowest was observed in Michi bora and the highest in Ronga chakua. Similar observation (0.08- $8.20 \%$ ) was reported by Das et al., (2018) for some brown form of chakua rice varieties of Assam.

The crude fat content of brown form of specialty rice of the present study was found to be lower than the values $(1.95 \%-3.83 \%)$ reported by Mudoi and Das, (2018) for some indigenous red grained cultivars of Assam. Pathak (2008) and Pathak (2015) also reported higher crude fat content for some hill rice cultivars of Assam (2.99\%- 5.27\%) and for some glutinous rice cultivars of Assam (2.64\%-3.76\%), respectively. The significant variation in the crude fat content of different brown forms of specialty rice might be due to the varietal differences.

In the present study, the crude fat content of different products and their intermittent forms varied from $0.10 \%-0.32 \%$, the lowest was observed in hurum and the highest in korai.
Similar observation (Komal chaul, Bhoja chaul, Flaked rice, Hurum, Sandahguri, and Korai to be $0.22 \%, 0.28 \%, 0.26 \%, 0.11 \%$, $0.18 \%$, and $0.31 \%$, respectively) was reported by Banik et al., (2018) for some traditional rice products of Assam.

In the present study, the crude fat content of flaked rice $(0.18 \%)$ was found to be lower than the values $(3.44 \%)$ reported by Kumar et al., (2016) for flaked rice. Kumar and Prasad, (2018) reported that the crude fat content of roasted rice and flaked rice were $3.33 \% \pm 0.19$ and $3.01 \% \pm 0.09$, respectively. In the present study, the lower crude fat content of flaked rice $(0.18 \%)$ was observed.

Kashyap and Mahanta, (2016) reported the crude fat of raw form of Teli chowkua (1.5\%) and Kola bora $(2.1 \%)$.

After processing, the same in kumal chawl made from Teli chowkua and Kola bora decreased to $1.4 \%$ and $2.0 \%$, respectively. In the present study too, crude fat content prepared from ronga chowkua variety recorded a decrease to $0.21 \%$ in kumal chawl from $0.41 \%$, present in brown form of the same variety.

The significant variation in the crude fat content of different brown form of specialty rice might be due to the varietal differences. The significant variation in the crude fat content of different products and their intermittent forms might be due to the changes of different nutrient components involved in method of processing (soaking, heating, frying, etc), because water soluble vitamins and minerals moved in to the grain during parboiling while the fat moved out (Dutta and Barua, 1978).

\section{The crude protein content}

The crude protein content of specialty rice and their products is presented in Table 1 and 
Figure 5. The crude protein content of brown form of specialty rice was found to be $5.83 \%$ to $6.61 \%$, the lowest was observed in Bakul bora and the highest in Ronga chakua. The result was similar with the values reported by Kumar et al., (2016) for brown rice (6.11\%).

Pathak (2015) reported that the protein content of some glutinous rice cultivars of Assam ranged from $8.10 \%-10.32 \%$ which was higher than the values observed in the present study. In the present study, the significant variation in the crude protein content of brown forms of specialty rice might be mainly due to the differences in genetical make up and soil nutrient status.

In the present study the crude protein content of different products and their intermittent forms varied from $6.23 \%-9.20 \%$, the lowest was observed in intermittent form 2 and the highest in sandah guri.

Similar observations were reported by Banik et al., (2018) for some traditional rice products of Assam (Komal chaul, Bhoja chaul, Flaked rice, Hurum, Sandahguri, and Korai to be $7.77 \%, 9.28 \%, 8.85 \%, 8.08 \%$, $7.85 \%$, and $7.83 \%$ ) respectively and Bagchi et $a l .,(2016)$ for popped rice $(7.0 \%-11.74 \%)$.

However, in the present study, the crude protein content of flaked rice $(7.43 \%)$ was found to be higher than the values (5.95 and $5.98 \%$ ) reported by Kumar et al., (2016) for thick flaked rice and extra thin flaked rice, respectively. Kumar and Prasad, (2018) reported that the crude protein content of roasted rice and flaked rice were 5.96 $\mathrm{g} / 100 \mathrm{~g} \pm 0.18$ and $5.82 \mathrm{~g} / 100 \mathrm{~g} \pm 0.27$, respectively.

Kashyap and Mahanta (2016) reported the protein content of raw form of Teli chowkua $(8.9 \%)$ and Kola bora (7.2\%) on dry basis and observed that the processing caused slight increase in protein content of kumal chawl prepared from Teli chowkua and Kola bora (9.3\% and $7.9 \%$, respectively). In the present study, kumal chawl was prepared from ronga chowkua variety and the crude protein content of kumal chawl and ronga chowkua were found to be $8.83 \%$ and $6.61 \%$, respectively suggesting increase in crude protein content due to komal chaul processing.

The significant variation in the crude protein content of different products and their intermittent forms prepared from the same variety might be due the percent changes involved in other dry matter components during processing, not being the actual change.

\section{The ash content}

The ash content of specialty rice and their products is presented in Table 1 and Figure 6. In the present study, the total ash content of brown form of specialty rice was found to be $0.66 \%$ to $0.92 \%$, the lowest was observed in Michi bora and the highest in Ronga chakua. Similar observations on ash content were reported by Das et al., (2018) for some brown form of chakua rice varieties $(0.66 \%-1.52 \%)$ and Mudoi and Das, (2018) for some indigenous red grained cultivars of brown rice of Assam (0.73\% - 1.85), respectively. Pathak (2015) reported that the ash content of some glutinous rice cultivars of Assam ranged between $1.00-2.00 \%$, which was higher than the values of present study. The variation in the total ash content of raw forms of specialty rice of different varieties might be due to the environmental factors such as soil type, ambient temperature during ripening and genetical makeup.

The ash content of different products and their intermittent forms varied from $0.75 \%$ $1.34 \%$, the lowest was observed in intermittent product 1 and the highest in hurum. Similar observations were reported by 
Barooah et al., (2018) for some traditional breakfast cereals of Assam (Komal chawl, Bora chawl, Sandahguri, Red rice and Red chira to be $1.02 \mathrm{~g} / 100 \mathrm{~g}, \quad 0.93 \mathrm{~g} / 100 \mathrm{~g}$, $1.10 \mathrm{~g} / 100 \mathrm{~g}, 1.67 \mathrm{~g} / 100 \mathrm{~g}$ and $2.06 \mathrm{~g} / 100 \mathrm{~g}$, respectively) and Banik et al., (2018) for some traditional rice products of Assam (Komal chaul, Bhoja chaul, Flaked rice, Hurum, Sandahguri, and Korai to be $0.83 \%$, $0.61 \%, 0.72 \%, 1.85 \%, 0.86 \%$, and $1.63 \%$, respectively ). In the present study, the ash content of different products and their intermittent forms were found to be lower than the value $(1.65 \%-1.73 \%)$ for flaked rice reported by Kumar et al., (2016). Kumar and Prasad, (2018) reported that the ash content of roasted rice and flaked rice were $1.33 \% \pm 0.09$ and $1.65 \% \pm 0.01$, respectively. In the present study, the lower ash content of flaked rice $(1.12 \%)$ was observed. Kashyap and Mahanta, (2016) reported on dry basis, the ash content of the raw rice Teli chowkua $(0.6 \%)$ and Kola bora (0.7\%). After processing, Teli chowkua kumal chawl had $0.7 \%$ ash and Kola bora kumal chawl had $0.8 \%$ ash. In the present study also after processing total ash content was found to be slightly increased. The komal chawl was prepared from ronga chowkua variety and the total ash content of komal chawl and ronga chowkua were $0.97 \%$ and $0.92 \%$, respectively.

Table.1 Proximate composition (\%, dry weight basis) of specialty rice and their products

\begin{tabular}{|l|l|l|l|l|l|l|l|}
\hline Rice forms & $\begin{array}{l}\text { Moisture(\%, } \\
\text { fresh weight }\end{array}$ & $\begin{array}{l}\text { Total Carbo- } \\
\text { hydrate }\end{array}$ & $\begin{array}{l}\text { Crude } \\
\text { protein }\end{array}$ & $\begin{array}{l}\text { Crude } \\
\text { fibre }\end{array}$ & Crude fat & Ash & $\begin{array}{l}\text { Energy } \\
\text { kcal/100g }\end{array}$ \\
\hline $\begin{array}{l}\text { Michi bora } \\
\text { (brown) }\end{array}$ & 11.51 & $91.71(81.15)$ & $6.49(5.74)$ & $0.78(0.69)$ & $0.35(0.31)$ & $0.66(0.58)$ & 395.95 \\
\hline Korai & 6.68 & $89.40(83.42)$ & $8.45(7.89)$ & $0.85(0.79)$ & $0.32(0.30)$ & $0.98(0.91)$ & 394.28 \\
\hline $\begin{array}{l}\text { Intermittent } \\
\text { form 1 }\end{array}$ & 13.50 & $90.87(78.60)$ & $7.05(6.09)$ & $1.07(0.92)$ & $0.25(0.22)$ & $0.75(0.65)$ & 393.93 \\
\hline Bhoja bora & 6.55 & $90.01(84.02)$ & $7.79(7.27)$ & $1.13(1.05)$ & $0.24(0.22)$ & $0.84(0.78)$ & 393.36 \\
\hline $\begin{array}{l}\text { Bakul bora } \\
\text { (brown) }\end{array}$ & 11.76 & $92.17(81.33)$ & $5.83(5.14)$ & $0.62(0.58)$ & $0.38(0.34)$ & $1.00(0.88)$ & 395.42 \\
\hline $\begin{array}{l}\text { Intermittent } \\
\text { form 2 }\end{array}$ & 14.43 & $91.63(78.41)$ & $6.23(5.33)$ & $0.71(0.61)$ & $0.28(0.24)$ & $1.15(0.98)$ & 393.96 \\
\hline Hurum & 8.16 & $90.97(83.55)$ & $6.90(6.34)$ & $0.76(0.70)$ & $0.10(0.09)$ & $1.34(1.23)$ & 392.38 \\
\hline Flaked rice & 13.43 & $90.47(78.32)$ & $7.43(6.43)$ & $0.77(0.67)$ & $0.18(0.16)$ & $1.12(0.97)$ & 393.22 \\
\hline $\begin{array}{l}\text { Rongachakua } \\
\text { (brown) }\end{array}$ & 14.05 & $91.12(78.31)$ & $6.61(5.68)$ & $0.93(0.80)$ & $0.41(0.35)$ & $0.92(0.79)$ & 394.61 \\
\hline Komalchaul & 11.13 & $88.97(79.07)$ & $8.83(7.85)$ & $1.01(0.90)$ & $0.21(0.19)$ & $0.97(0.86)$ & 393.09 \\
\hline Sandahguri & 8.51 & $88.53(80.99)$ & $9.20(8.42)$ & $1.05(0.96)$ & $0.14(0.13)$ & $1.07(0.98)$ & 392.18 \\
\hline Mean & 10.88 & $90.53(80.65)$ & $7.35(6.56)$ & $0.88(0.78)$ & $0.26(0.23)$ & $0.98(0.87)$ & 393.85 \\
\hline CD(0.05) & 0.534 & 0.372 & 0.197 & 0.012 & 0.016 & 0.016 \\
\hline SE(m) & 0.181 & 0.130 & 0.067 & 0.004 & 0.005 & 0.006 \\
\hline SE(d) & 0.256 & 0.183 & 0.094 & 0.006 & 0.008 & 0.008 \\
\hline
\end{tabular}

Data in parentheses represent the values at corresponding moisture content of the raw rice/ products 


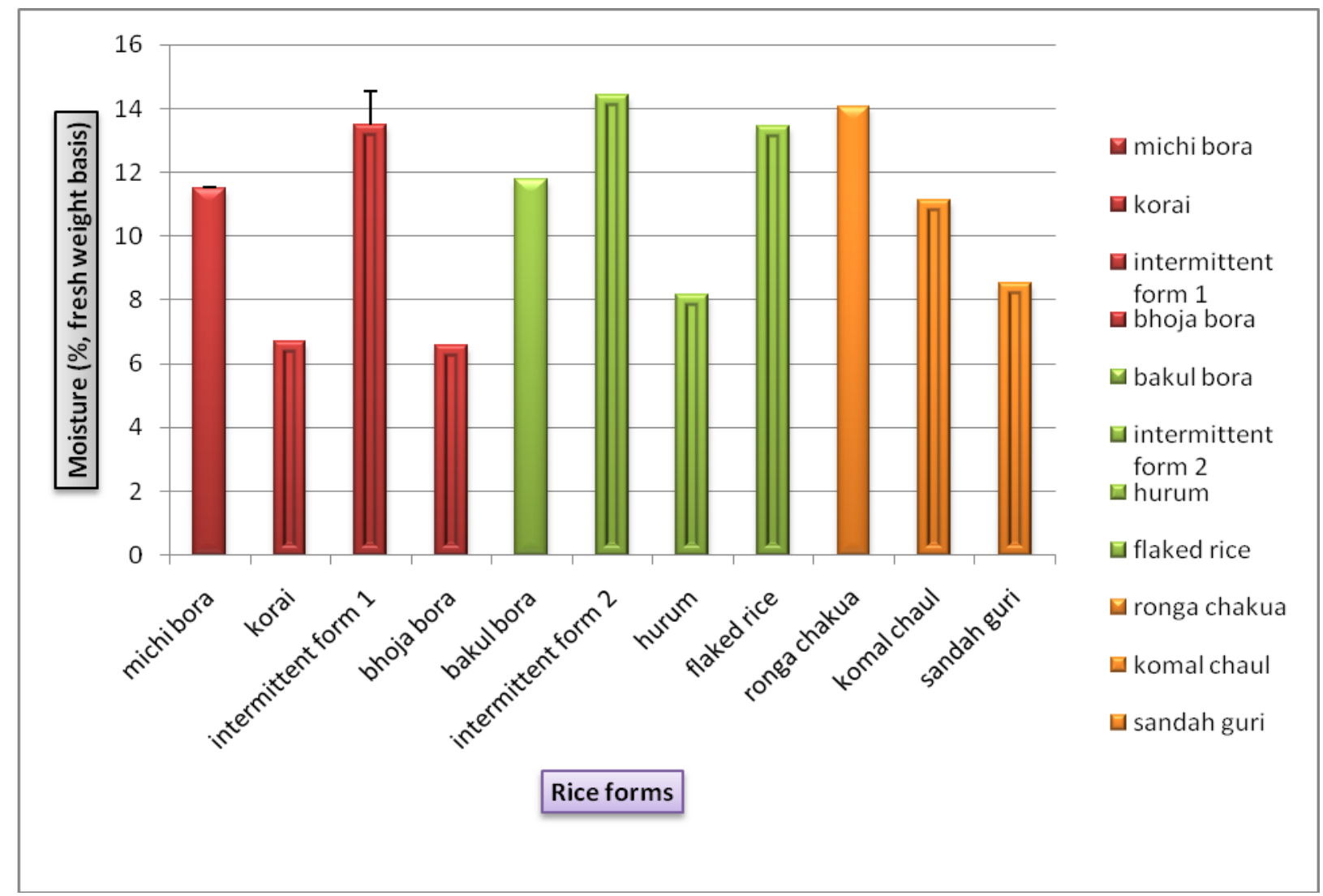

Fig.1 Moisture content (\%, fresh weight basis) of specialty rice and their products

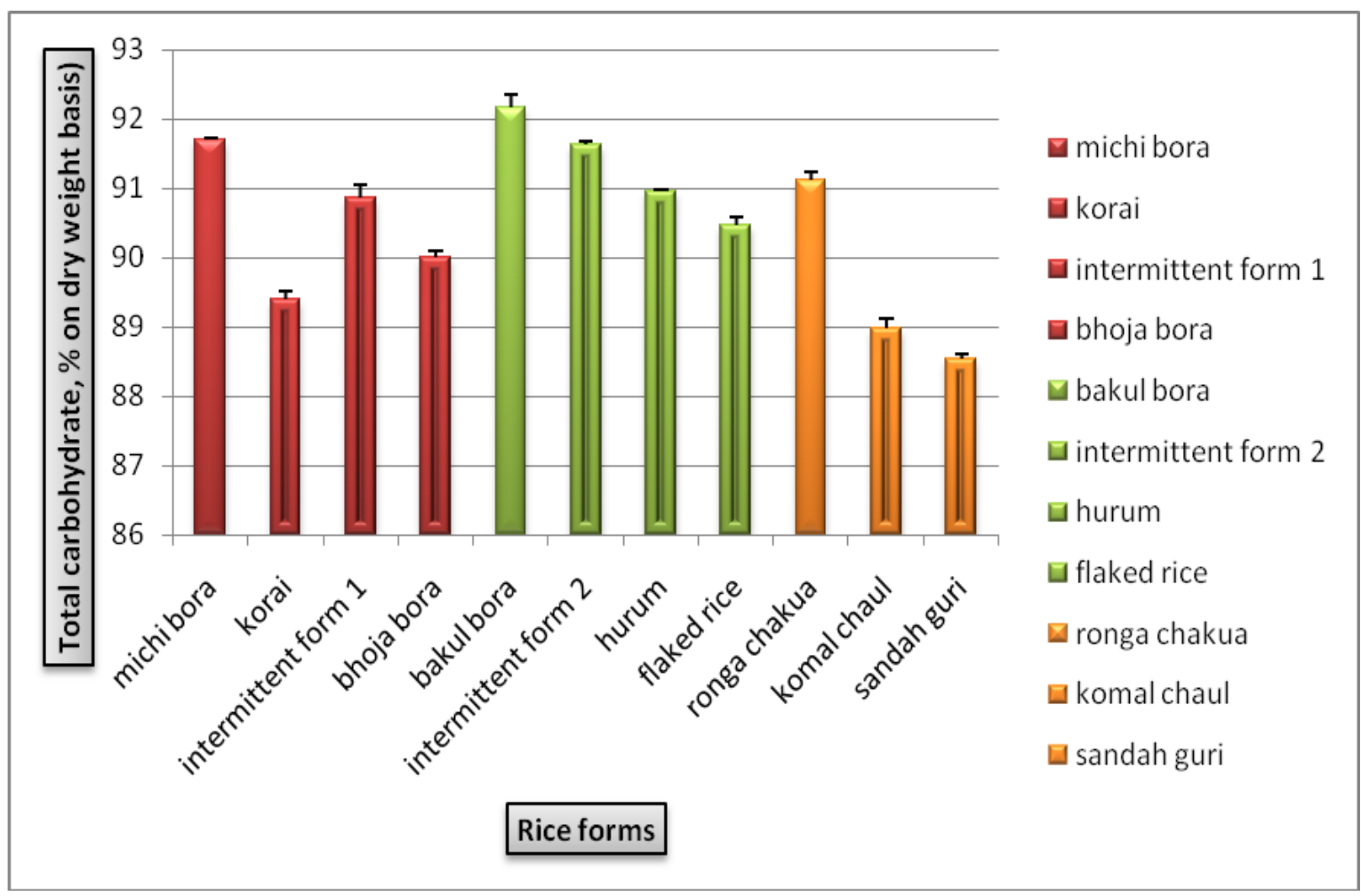

Fig.2 Total carbohydrate content (\%, dry weight basis) of specialty rice and their products 


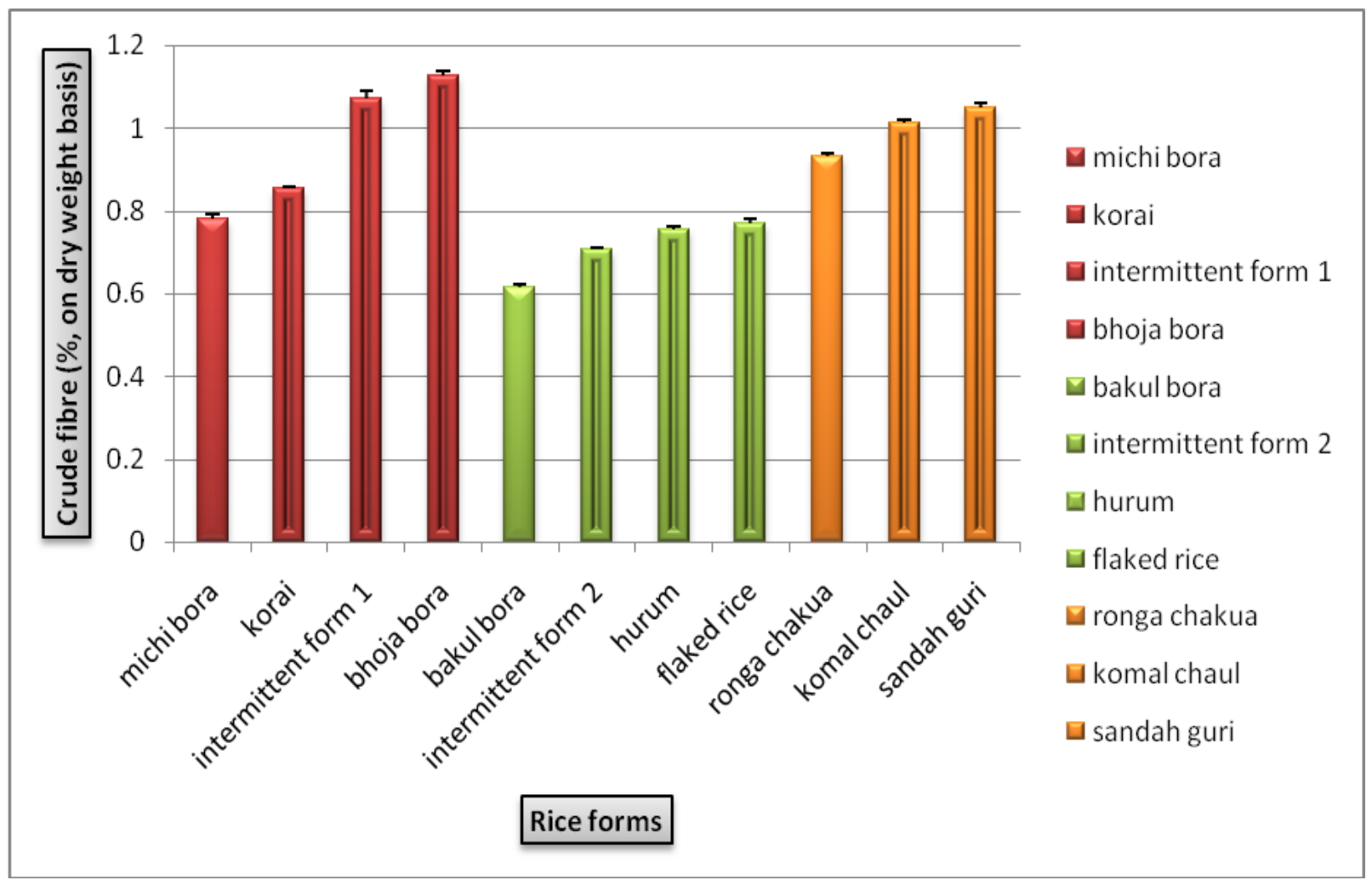

Fig.3 Crude fibre content (\%, dry weight basis) of specialty rice and their products

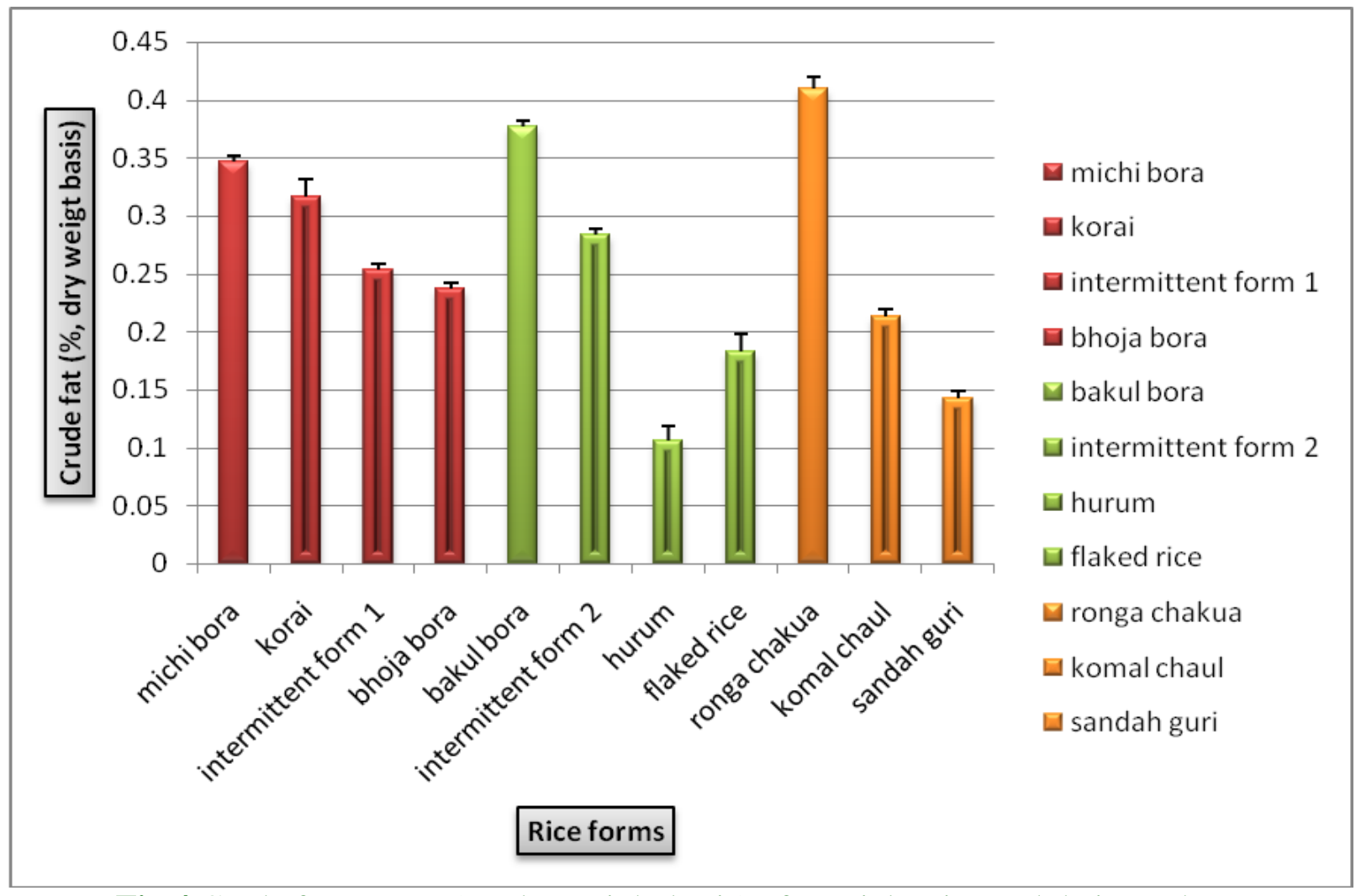

Fig.4 Crude fat content (\%, dry weight basis) of specialty rice and their products 


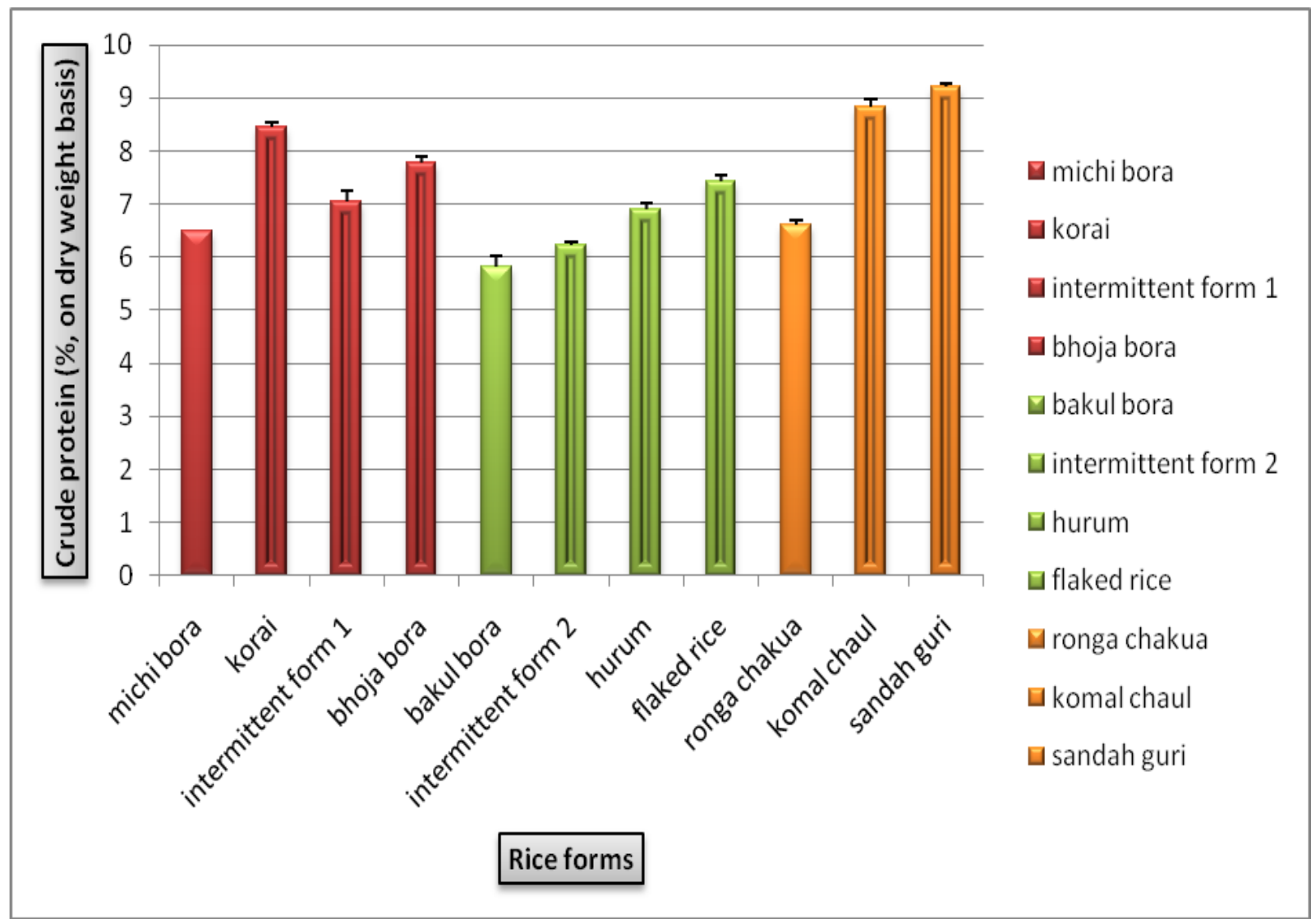

Fig.5 Crude protein content (\%, dry weight basis) of specialty rice and their products

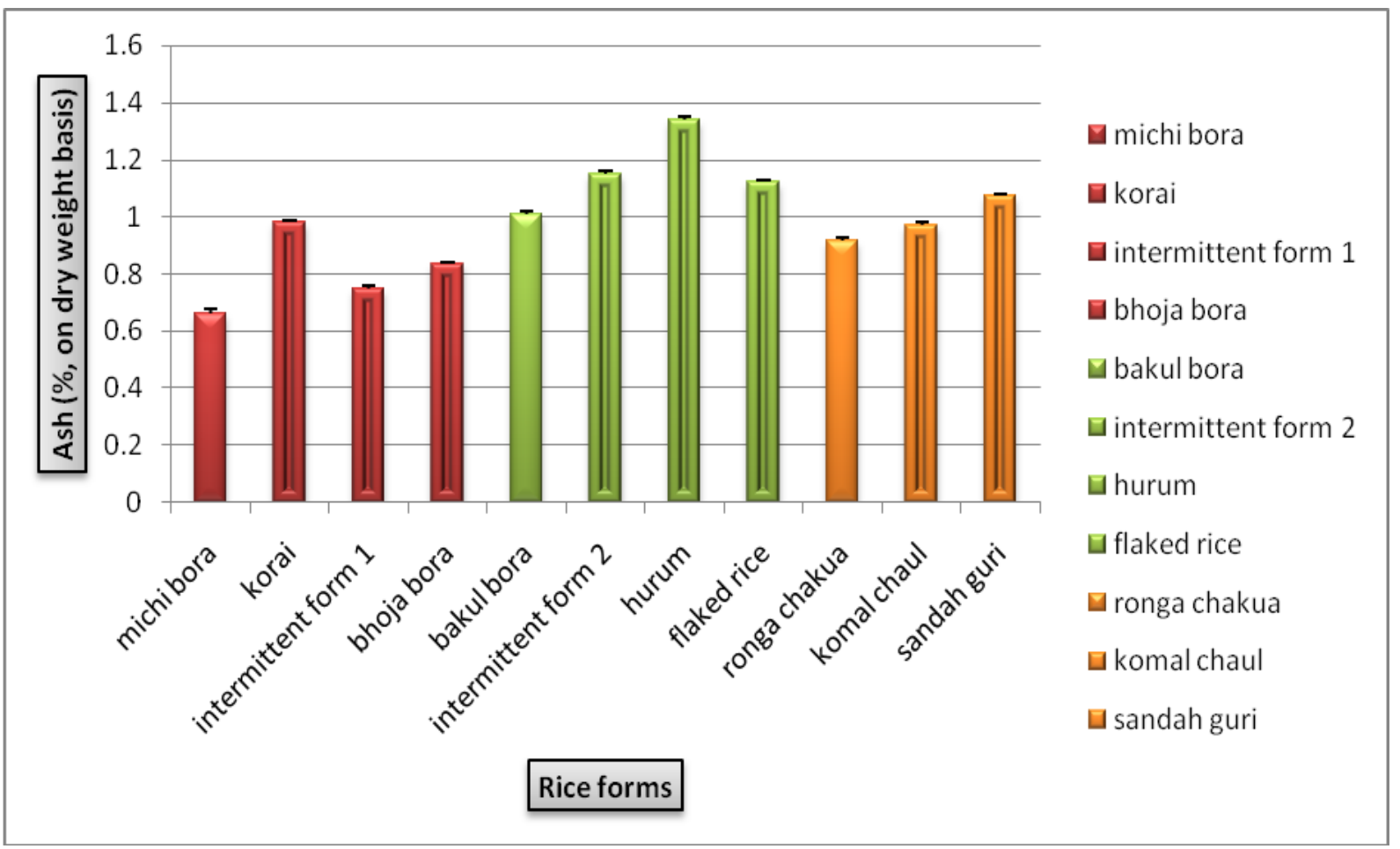

Fig.6 Ash content (\%, dry weight basis) of specialty rice and their products 
The significant variation in the total ash content of different products and their intermittent forms of the same variety might be due to the differences in method of processing involved. Kale et al., (2015) suggested that soaking changed fibre, ash and mineral compositions in rice and also brought diffusion of color pigments, fat globules, etc, from husk and bran layers into starchy endosperm.

The observed higher ash content in korai than the respective raw form might be mainly due to increase in percentage as during sieving, a hard portion which was greater in size (more than $50 \mu$ ) was rejected. The hard portion might be composed of starch as during this step, significant decrease in starch content was also observed, which we reported earlier (Bhattacharjee et al, 2019). As sandah guri was also collected after sieving, the increase in ash content can be justified as mentioned above.

\section{The energy content}

The energy content of brown form of specialty rice were found to be 394.61$395.95 \mathrm{kcal} / 100 \mathrm{~g}$; the lowest in Ronga chakua and the highest in Michi bora. The energy content of specialty rice of present investigation was found to be slightly higher than the value (349.84- $389.16 \mathrm{kcal} / 100 \mathrm{~g})$ reported by Das et al., (2018) for brown form of chakua rice varieties of Assam.

The energy content of specialty rice products and their intermittent forms were found to be 392.18 - $393.96 \mathrm{kcal} / 100 \mathrm{~g}$; the lowest in sandah guri and the highest in intermittent form 2. The energy content decreased in the specialty rice products than their respective raw forms, which might be due to loss of carbohydrate and crude fat during processing. Banik et al., (2018) reported the energy values for komal chaul, bhoja chaul, and flaked rice, hurum, sandahguri and korai to be $394.18 \mathrm{kcal} / 100 \mathrm{~g}, 394.32 \mathrm{kcal} / 100 \mathrm{~g}$, $395.66 \mathrm{kcal} / 100 \mathrm{~g}, 390.63 \mathrm{kcal} / 100 \mathrm{~g}, 393.30$ $\mathrm{kcal} / 100 \mathrm{~g}$ and $391.31 \mathrm{kcal} / 100 \mathrm{~g}$, respectively.

The same pattern of change of macronutrient were observed for the two products made from each of the three rice varieties ( in total six products). Korai and Bhoja bora were made from Michi bora variety, hurum and flaked rice were processed from Bakul bora variety, and komol chaul and sandahguri were processed from Ranga chakuwa varitey.

Decrease for moisture, total carbohydrate and crude fat content and increase for crude protein, crude fibre and ash content were observed in the products than their respective raw forms. In comparison to bhaja bora, korai contained the higher amount of crude protein, crude fat, ash and energy. Similarly, in comparison to flaked rice, hurum contained higher amount of ash and total carbohydrate. Sandah guri contained the higher amount of crude protein and crude fibre than komol chaul. Detection of higher crude protein, ash and crude fibre content due to processing emphasizes the nutritional importance of these ethnic rice products in our daily diet.

\section{References}

A.O. A. C. (2000). Official Methods of Analysis. 17th Edn. Association of Analytical Chemists, Arlington, VA, USA.

Atungulu, G.G. and Pan, Z. (2014). Rice industrial processing world wide and impact on macro- and micronutrient content, stability, and retention. Ann. N.Y. Acad. Sci. 1324: 15-28.

Bagchi, T.B., Sanghamitra, P., Berliner, J.K., Sarkar, A., Kumar, A., Ray, S. and Sharma, S. G. (2016). Assessment of physicochemical, functional and nutritional properties of raw and traditional popped rice. Indian. J. Trad. 
Knowledge. 15(4): 659-668.

Banik, R., Das, P., Deka, N. and Sarmah, T.C. (2018). Ready to use ethnic rice products of Assam, India: Potential source of resistant Starch. Bull. Env. Pharmacol. Life Sci. 7(4): 55-58.

Barooah, M.S., Das, M., Chatterjee, L., Baruah, C. and Khatoniar, S. (2018). Nutrient composition of some traditional breakfast cereals of Assam. Int. J Chem. Studies. 6(3): 2535-2537.

Bhattacharjee, S., Das, P., Pathak, K., Nath, T., Ojha, N. and Barua,S. (2019). Carbohydrate profiling of a few rice products of Assam having ethnoeconomic importance. Int. J. Curr. Microbiol. App. Sci. 8(12): 2902- 2912.

Das, P., Singha, A.D., Goswami, K. and Sarmah, K. (2018). Detection of Nutritionally Significant Indigenous Rice Varieties from Assam, India. Bull. Env. Pharmacol. Life Sci. 7(4): 59-64

Dutta, L. and Barua, J. (1978). Nutrient composition of glutinous and nonglutinous rice varieties grown in Assam. Indian. J. Agric Sci. 48(10): 610-613.

Gopalan, G., Ramasastri, B.V. and Balasubramanian, S.C. (2000). Nutritive value of Indian Foods. Indian. Council. Med Res. Hyderabad. 47.

Kale, S. J., Jha, S. K., Jha, G.K., Sinha, J.P. and Lal, S. B. (2015). Soaking induced changes in chemical composition, glycemic index and starch characteristics of basmati rice. Rice. Sci. 22(5): 227-236.

Kashyap, A. and Mahanta, C. L. (2016). Physical properties and nutritive value of a popular Assamese breakfast cereal. Int. J. Home Sci. 2(2): 227-231.
Kennedy, G. and Burlingame, B. (2003). Analysis of food composition data on rice from a plant genetic resource perspective. Food. Chem. 80(4): 589-596

Kumar, S., Haq, R. U. and Prasad, K. (2016). Studies on physico-chemical, functional, pasting and morphological characteristics of developed extra thin flaked rice. $J$. Saudi Society Agric. Sci. 17(3): 259-267.

Kumar,S. and Prasad, K. (2018). Changes in the characteristics of indica rice on the process of flaking. Int. J. Chem. Studies. 6(2): 2310-2317.

Mahadevamma, S. and Taranathan, R.N. (2007). Processed rice starch characteristics and morphology. European Food Res. Technol. 225(3-4): 603-612.

Mudoi, T. and Das, P. (2018). Nutritional composition of traditional colored rice cultivars of Assam, India. Bull. Env. Pharmacol. Life Sci. 7(7): 10- 14.

Pathak, K. (2008). Starch and protein profile of some hill rice (Oryza sativa L.) cultivars of Assam. M.Sc (Agri) Thesis, Assam Agricultural University, Jorhat.

Pathak, K. (2015). Bio prospecting of glutinous rice of Assam. PhD (Agri) Thesis, Assam Agricultural University, Jorhat.

Pinkrova, J., Hubackova, B., Kadlec P., Prihoda, J. and Bubnik, Z. (2003): Changes of starch during microwave treatment of rice. Czech. J. Food Sci. 21: 176- 184.

Svihus, B., Uhlen, A. K. and Harstad, O. M. (2005). Effect of starch granule structure, associated components and processing on nutritive value of cereal starch: A review. Animal Feed. Sci. Technol. 122: 303-320.

\section{How to cite this article:}

Suchandra Bhattacharjee and Priyanka Das. 2020. Changes in Proximate Composition during Processing of a Few Rice Products of Assam having Ethno-Economic Importance. Int.J.Curr.Microbiol.App.Sci. 9(04): 713-725. doi: https://doi.org/10.20546/ijcmas.2020.904.085 